\title{
Experimental and Numerical Studies of a Recuperator in Micro Turbines
}

\author{
Xusheng $\mathrm{Shi}^{1,2}$, Yongwei Wang ${ }^{1,2^{*}}$, and Xiulan Huai ${ }^{1,2^{* *}}$ \\ ${ }^{1}$ Institute of Engineering Thermophysics, Chinese Academy of Sciences, Beijing, 100190, China \\ ${ }^{2}$ University of the Chinese Academy of Sciences, Beijing, 100049, China
}

\begin{abstract}
In this pa per, a recuperator $\mathrm{m}$ odel is e stablished to $\mathrm{s}$ imulate the $\mathrm{r}$ eal working $\mathrm{s}$ tate of the recuperator in the micro turbine. The relative error between simulated and experimental data doesn't exceed $5 \%$, which indicates that the model can $b$ etter $r$ eflect the ch anging 1 aw of the recuperator performance. Therefore, $t$ he recuperator model pr oposed i $n$ this pa per i $\mathrm{s} r$ easonable a nd $\mathrm{r}$ eliable. I $\mathrm{n}$ a ddition, $\mathrm{t}$ he simulation results indicate that heat transfer efficiency is not sensitive to the change of hot inlet temperature, however, it increases with the decrease of mass flow rate. On the other hand, the decrease of inlet mass flow leads to the relative pressure loss decreased on hot and cold sides.
\end{abstract}

\section{Introduction}

Micro $t$ urbines $h$ ave $b$ een widely used in o il a nd gas industry, $p$ ower $g$ eneration and other fields because of their a dvantages of s imple and co mpact structure and low pollution. The adoption of efficient recuperated cycle technology $\mathrm{c}$ an gr eatly i mprove t heir t hermal efficiency t o meet eco nomic $r$ equirements [1]. The compact an $\mathrm{d}$ ef ficient $\mathrm{r}$ ecuperator i s o ne of $\mathrm{t}$ he $\mathrm{k}$ ey equipments in micro turbines.

Many scholars have done a lot of work on the development of recuperator performance simulation and optimization. Xiao et al.[2] reviewed the types, materials, manufacturing, o perating ch aracteristics an $d$ performance optimization of recuperator. Wang et al.[3] reviewed the development a nd ap plication of $\mathrm{s}$ everal high-efficiency s urface heat ex changers. Dong e t a 1.[4] obtained the heat transfer and pressure loss correlations of the $w$ avy $f$ in and $f$ lat $t$ ube heat e xchangers by experiments. Do et al.[5] experimentally investigated the pressure $d$ rop an $d h$ eat $t$ ransfer ch aracteristics o f a recuperator $w$ ith o ffset $s$ trip $f$ ins and pr oposed two analytical models to p redict the p ressure $d$ rop and heat transfer characteristics of the fabricated recuperator. Kim et a 1.[6] refined the recuperator characteristic m odels improved simulation accuracy.

At $\mathrm{p}$ resent, $\mathrm{t}$ he $\mathrm{p}$ erformance an alysis o $\mathrm{f}$ micro turbines us ually a dopts the general recuperator simulation model $r$ ather $t$ han the accu rate $p$ erformance based on the experiment. The general model ignores the anisotropy of the recuperator geometry and heat exchange $\mathrm{u}$ nit, and $\mathrm{i} \mathrm{t}$ does no $\mathrm{t}$ fully $\mathrm{c}$ onsider $\mathrm{t}$ he important factors affecting the recuperator performance, and 1 acks o f ex perimental co rrection. Therefore, it cannot t ruly r eflect the performance c hange law of the micro turbine recuperator.

In $\mathrm{v}$ iew of the s hortcomings of the ab ove r esearch, the $\mathrm{p}$ erformance o $\mathrm{f}$ recuperator will $\mathrm{b}$ e $\mathrm{s}$ tudied experimentally in this $\mathrm{p}$ aper. And the numerical model was es tablished. $\mathrm{T}$ he $\mathrm{n}$ umerical $\mathrm{s}$ imulation $\mathrm{r}$ esults ar $\mathrm{e}$ compared $w$ ith $t$ he ex perimental $r$ esults $t$ o $p$ rove $t$ he correctness o $\mathrm{ft}$ he model. $\mathrm{T}$ hen $\mathrm{t}$ he $\mathrm{p}$ erformance o $\mathrm{f}$ recuperator under $\mathrm{d}$ ifferent $\mathrm{o}$ perating $\mathrm{c}$ onditions is studied.

\section{Recuperator and experiment rig}

\subsection{Recuperator}

The recuperator in this paper is a plate heat exchanger, which has c ompact s tructure a nd high heat e xchange efficiency. $\mathrm{T}$ he $\mathrm{s}$ tructure of cold an $\mathrm{d} h$ ot ch annels is shown in Fig. 1. (a)

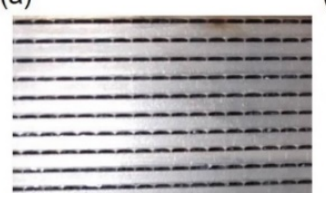

(b)

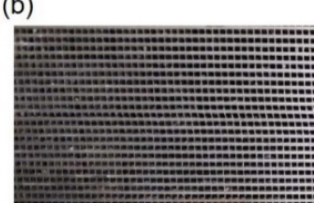

Fig. 1. Cold and hot channels of plate heat exchanger.

\subsection{Experiment rig}

The recuperator ex periment test $r$ ig is shown in fig. 2, which includes $r$ ecuperator test $\mathrm{p}$ ieces, a ir $\mathrm{s}$ ystem, heating system and measurement system, etc. Due to the

\footnotetext{
${ }^{*}$ Corresponding author's e-mail: wangyongwei@iet.cn

*** Corresponding author's e-mail: hxl@iet.cn
} 
coupling of pr essure a nd flow rate of fluid, s olenoid valve and back pressure valve in the air system need to be a djusted s imultaneously during t he e xperiment $t o$ obtain th e $r$ equired flow rate and $p$ ressure. And the power of electric heater in the heating system should be adjusted, so as to simulate the real working condition of

(a)

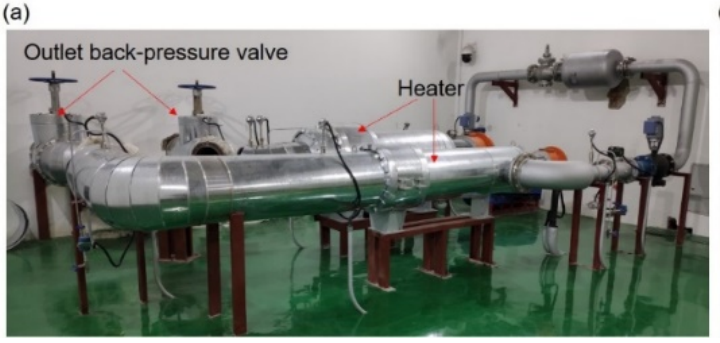

micro turbine recuperator. In addition, the blower in the air system provides low-pressure air for the hot side to simulate the gas turbine outlet flow; the air co mpressor provides high pressure air to the cold side to simulate the compressor outlet flow. The measured system parameters are shown in table 1.

(b)

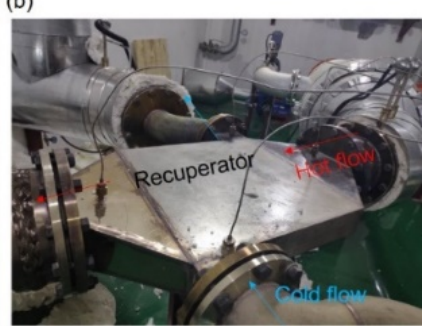

Fig. 2. Recuperator experiment test rig.

Table 1. Recuperator test rig measurement system

\begin{tabular}{ccccc}
\hline Measured parameters & Measuring equipment & Accuracy $/ \%$ & Number & Range \\
\hline Temperature (before heating) & Pt1000 & \pm 0.2 & 2 & $0 \sim 100^{\circ} \mathrm{C}$ \\
Temperature (after heating, cool flow) & Pt1000) & \pm 0.2 & 1 & $0 \sim 300^{\circ} \mathrm{C}$ \\
Temperature (cool flow inlet) & Pt1000 & \pm 0.2 & 1 & $0 \sim 300^{\circ} \mathrm{C}$ \\
Temperature (cool flow outlet) & K type Thermocouple & \pm 0.75 & 1 & $0 \sim 800^{\circ} \mathrm{C}$ \\
Temperature (after heating, hot flow) & K type Thermocouple & \pm 0.75 & 1 & $0 \sim 800^{\circ} \mathrm{C}$ \\
Temperature (hot flow inlet) & K type Thermocouple & \pm 0.75 & 1 & $0 \sim 800^{\circ} \mathrm{C}$ \\
Temperature (hot flow outlet) & K type Thermocouple & \pm 0.75 & 1 & $0 \sim 800^{\circ} \mathrm{C}$ \\
Pressure (cool flow) & Pressure transmitter & \pm 0.2 & 3 & $0 \sim 0.5 \mathrm{MPa}$ \\
Pressure (hot flow) & Pressure transmitter & \pm 0.2 & 3 & $0 \sim 0.1 \mathrm{MPa}$ \\
Mass flow & Gas turbine meter & \pm 1.5 & 2 & $65 \mathrm{~m}^{3} / \mathrm{h} \sim 1300 \mathrm{~m}^{3} / \mathrm{h}$ \\
\hline
\end{tabular}

\section{3. numerical modeling}

In $\mathrm{t}$ his $\mathrm{p}$ aper, $\mathrm{F}$ lownex $\mathrm{SE}$ ( thermodynamic $\mathrm{s}$ ystem simulation $\mathrm{s}$ oftware) were $\mathrm{u}$ sed $\mathrm{f}$ or $\mathrm{t}$ he $\mathrm{n}$ umerical modelling a nd s imulation. The s oftware is suitable for design an $\mathrm{d} s$ imulation o $\mathrm{f}$ ae rospace an $\mathrm{d}$ o ther $\mathrm{r}$ elated industry $t$ hermodynamics a nd $t$ urbomachinery network problems. It has s tandard 1 ibrary co mponents s uch as turbines, compressors, pipes, and heat transfer elements, which a llows easy forming of turbomachinery networks and $r$ ecuperator model. A F lownex user ca $n$ a nalyze a standard $t$ urbomachine a nd a dd an d an alyze ad ditional components. Figure 3 describes the Flownex recuperator model. $\mathrm{T}$ he $\mathrm{m}$ odel $\mathrm{c}$ onsists of $\mathrm{h}$ ot a nd $\mathrm{c}$ old inlet boundary properties, hot and cold channels, heat transfer elements, $r$ adiation to $t$ he $\mathrm{e}$ nvironment and outlet boundary $\mathrm{c}$ onditions. $\mathrm{T}$ he connecting no des $\mathrm{i} \mathrm{nt}$ he network system join the network elements smoothly and ensure go od network communication between the elements.

In o rder to v erify the co rrectness of the model, the simulation $r$ esults ar e co mpared with the ex perimental results, as shown in Table 2 . Simulation results in dicate that the relative error between simulated and experimental data d oesn't e xceed $5 \%$. The co rrectness and validation of the simulation model is demonstrated.

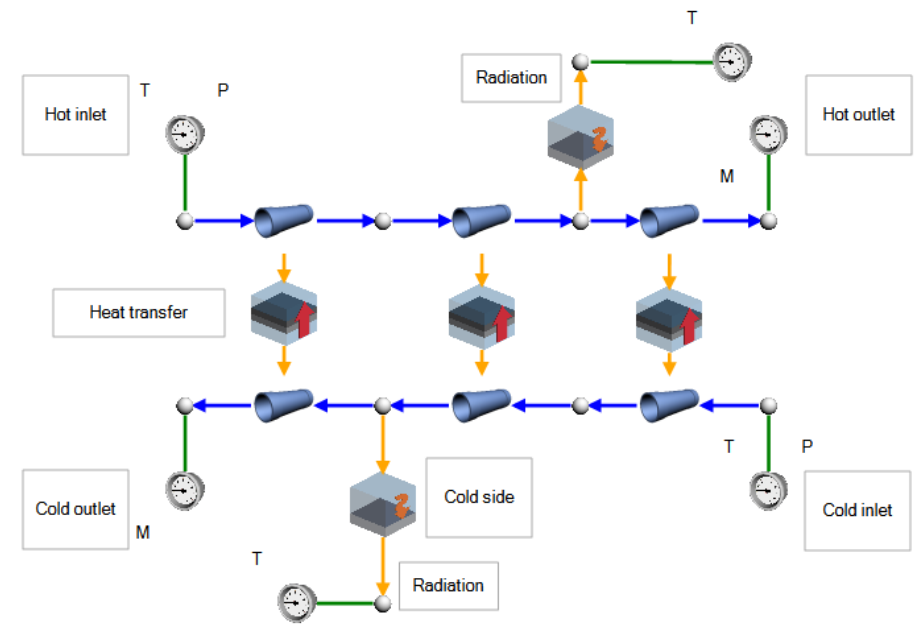

Fig. 3. Flownex SE recuperator model. 
Table 2. The correctness and validation of the simulation model

\begin{tabular}{|c|c|c|c|}
\hline & $\begin{array}{l}\text { experimental } \\
\text { result }\end{array}$ & simulated result & relative error \\
\hline Mass flow (hot) & $0.205 \mathrm{~kg} / \mathrm{s}$ & $0.205 \mathrm{~kg} / \mathrm{s}$ & - \\
\hline Inlet temperature (hot) & $564.3^{\circ} \mathrm{C}$ & $564.3^{\circ} \mathrm{C}$ & - \\
\hline Inlet pressure (hot) & $112.45 \mathrm{kPa}$ & $112.45 \mathrm{kPa}$ & - \\
\hline Temperature difference between inlet and outlet (hot) & $173.5^{\circ} \mathrm{C}$ & $177.4^{\circ} \mathrm{C}$ & $2.25 \%$ \\
\hline Pressure difference between inlet and outlet (hot) & $0.96 \mathrm{kPa}$ & $0.961 \mathrm{kPa}$ & $0.1 \%$ \\
\hline Mass flow (cold) & $0.128 \mathrm{~kg} / \mathrm{s}$ & $0.128 \mathrm{~kg} / \mathrm{s}$ & - \\
\hline Inlet temperature (cold) & $304.3^{\circ} \mathrm{C}$ & $304.3^{\circ} \mathrm{C}$ & - \\
\hline Inlet pressure (cold) & $383 \mathrm{kPa}$ & $383 \mathrm{kPa}$ & - \\
\hline Temperature difference between inlet and outlet (cold) & $225.5^{\circ} \mathrm{C}$ & $222.08^{\circ} \mathrm{C}$ & $1.52 \%$ \\
\hline Pressure difference between inlet and outlet (cold) & $26.14 \mathrm{kPa}$ & $25.78 \mathrm{kPa}$ & $1.38 \%$ \\
\hline
\end{tabular}

\section{Results and discussion}

The heat transfer efficiency is defined as:

$$
\varepsilon=\frac{T_{\text {cool,out }}-T_{\text {cool,in }}}{T_{\text {hot,in }}-T_{\text {cool, in }}}
$$

where $T_{\text {hot,in }}, T_{\text {cool,in }}$ and $T_{\text {cool,out }}$ are h ot f low i nlet temperature, c old flow in let te mperature and c old flow outlet temperature, respectively.

The relative pressure loss of hot side is calculated as:

$$
\delta p_{\text {hot }}=\frac{p_{\text {hot,in }}-p_{\text {hot,out }}}{p_{\text {hot,in }}} \times 100 \%
$$

where $p_{\text {hot,in }}$ and $p_{\text {hotout }}$ are h ot f low i nlet $\mathrm{p}$ ressure and hot flow outlet pressure, respectively.

The relative pressure loss of cold side:

$$
\delta p_{\text {cold }}=\frac{p_{\text {cold,in }}-p_{\text {cold,out }}}{p_{\text {cold,in }}} \times 100 \%
$$

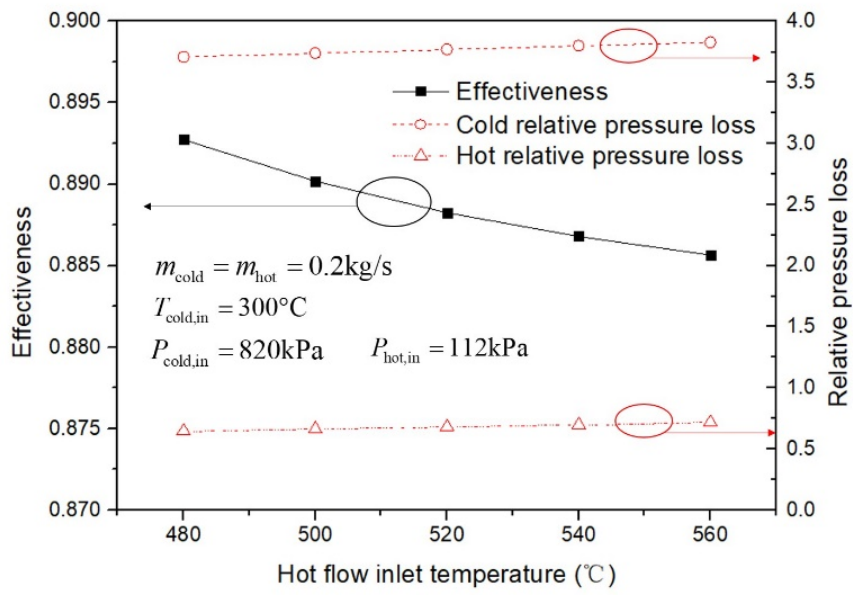

Fig. 4. Effect of hot flow inlet temperature.

\section{Conclusion}

In $\mathrm{t}$ his $\mathrm{p}$ aper, the $\mathrm{r}$ ecuperator model i s es tablished $\mathrm{t} \mathrm{o}$ simulate the real working state of the recuperator in the micro turbine. The relative error between simulated and experimental $\mathrm{d}$ ata $\mathrm{d}$ oesn't ex ceed $5 \%$, wh ich indicates that the model can better reflect the changing law of the recuperator performance. $\mathrm{T}$ herefore, $\mathrm{t}$ he recuperator where $p_{\text {cold,in }}$ and $p_{\text {cold,out }}$ are cold flow inlet pressure and cold flow outlet pressure, respectively.

Figure $4 \mathrm{~s}$ hows $\mathrm{t}$ he e ffect o fho $\mathrm{tf}$ low $\mathrm{i}$ nlet temperature ranging from 480 to $560^{\circ} \mathrm{C}$ on heat transfer efficiency and relative pressure loss of hot and cold side. It can be seen that heat transfer efficiency is not sensitive to the $\mathrm{c}$ hange of hot i nlet te mperature. This is b ecause the structure and working medium of the recuperator are fixed, the c hanging of ho $t$ flow i nlet t emperature $\mathrm{c}$ an't improve $t$ he $h$ eat transfer $\mathrm{c}$ oefficient of hot an $\mathrm{d}$ co ld sides. In a ddition, the relative p ressure lo ss of the cold side $\mathrm{r}$ emained unchanged, while the h ot s ide i ncreased with the increase of the hot flow inlet temperature.

Figure 5 shows the effect of mass flow rate ranging from 0.1 to $0.3 \mathrm{~kg} / \mathrm{s}$ on heat transfer e fficiency and relative pressure loss of hot and cold side. It can be seen that heat transfer ef ficiency increases with the decrease of mass flow rate. In addition, the decrease of inlet mass flow leads to the relative pressure loss decreased on both sides.

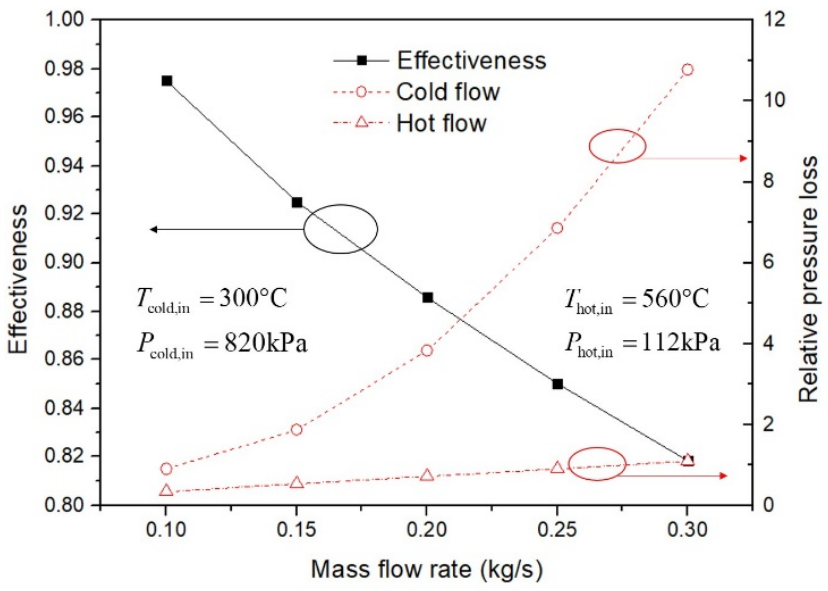

Fig. 5. Effect of inlet mass flow rate.

model proposed in this paper is reasonable and reliable. In addition, the simulation results indicate that heat transfer ef ficiency is not s ensitive to the c hange of ho $t$ inlet temperature, however, it increases with the decrease of $\mathrm{m}$ ass $\mathrm{fl}$ ow rate. On the o ther ha nd, the d ecrease of inlet mass flow 1 eads $t$ o t he $r$ elative $p$ ressure 1 oss decreased on hot and cold sides. 
This study was supported by the Key Research Program of the Chinese Academy of Sciences (ZDRW-CN-2017-2).

\section{References}

1. C.F. McDonald. Appl T herm E ng. 23, 1463-1487 (2003).

2. G. Xiao, T. Yang, H. Liu, D. Ni, M.L. Ferrari, M. Li, et al. Appl Energy. 197, 83-99 (2017).
3. Q. W ang, M. Z eng, T. Ma, X. D u, J . Yang. A ppl Energy. 135, 748-777 (2014).

4. D. J unqi, C . J iangping, C. Z hijiu, Z. Y imin, Z. Wenfeng. Appl Therm Eng. 27, 2066-2073 (2007).

5. K.H. Do, B.-I. Choi, Y.-S. Han, T. Kim. Int J Heat Mass Transfer. 103, 457-467 (2016).

6. M.J. K im, J .H. K im, T.S. K im. Appl T herm En g. 108, 122-130 (2016). 